\title{
Bent Spine Syndrome: A Phenotype of Dysferlinopathy or a Symptomatic DYSF Gene Mutation Carrier
}

\author{
István Gátia, e Olof Danielsson ${ }^{\text {a, e }} \quad$ Cecilia Gunnarsson ${ }^{b} \quad$ Magnus Vrethem ${ }^{\text {d, e }}$ \\ Bo Häggqvist $^{a}$ Bengt-Arne Fredriksson ${ }^{c}$ Anne-Marie Landtblom ${ }^{e, f}$ \\ Divisions of a Neurosciences, ${ }^{b}$ Pathology and Clinical Genetics and ${ }^{\mathrm{C}}$ Experimental Pathology, Department of \\ Clinical and Experimental Medicine, d Department of Clinical Neurophysiology, and e Neurology Clinic, Linköping \\ University, Linköping, and ${ }^{\mathrm{f}}$ Neurology Unit, Motala General Hospital, Motala, Sweden
}

Dear Sir,

A bent spine can result from paraspinal muscle weakness of different causes. The symptom has also been described as bent spine syndrome or camptocormia $[1,2]$. More or less incomplete fatty degeneration of the erector spine muscles has been found in these cases [3,4]. While camptocormia is an age- and disorder-related symptom, the primary degeneration of the erector spinae muscles is regarded as a muscle disorder, and denominated as bent spine syndrome. Different etiology could result in paraspinal muscle weakness, such as inflammatory myopathies $[5,6]$, metabolic disorders $[7,8]$ and, rarely, genetically determined degenerative muscle disorders such as ryanodine receptor gene (RYR1) mutation [9], D4Z4 gene mutations (which characterize facioscapulohumeral dystrophy $[4,10])$ and, as described in one case, a DYSF gene mutation [3]. We present the history of a 67-year-old woman with bent spine syndrome, in whom the mutation of the DYSF gene also was the probable background of bent spine syndrome.

\section{Case History}

This 67-year-old woman had been followed up at our department for about 5 years. There were no complaints or symptoms of a similar nature in her family his- tory. She had good muscle prowess in her childhood, but was not very active in sport before the onset of her complaints. Her symptoms started approximately 15 years ago with a slowly progressive gait disturbance. It had become difficult to climb stairs and to stay upright. Later in the course, she also noted mild muscle weakness in her shoulder girdle.

The physical neurological investigation revealed severe thoracic kyphosis in the standing position, without physical signs of spondylosis or muscle spasticity (fig. 1a). A moderate paresis was also found in the abductor muscle of the shoulder girdle. Tendon reflexes were weak but symmetric. No limb ataxia, trunk ataxia or sensory loss was present. The physical symptoms were characteristic for bent spine syndrome. Routine laboratory parameters like liver and muscle enzyme levels, including serum CK level, were within normal range.

Electromyography (EMG) of the vastus lateralis and tibialis anterior muscles did not show any signs of denervation. The interference pattern was normal, and a mixture of both high- and low-amplitude muscle action potentials was found, with an increase of polyphasic muscle action potentials. EMG of the paraspinal, infraspinatus and deltoid muscles, however, showed a typical myopathic pattern with low-amplitude, thin muscle action potentials. No denervation activity was seen. Tibialis somatosensory-evoked potentials were normal.

MRI investigation demonstrated atrophy and fatty degeneration of the erector spinae muscles, with dominance on the right side (fig. 1b).

Muscle biopsy of the deltoid muscle demonstrated moderate signs of myopathy with an increased number of internal nuclei, some rod body-like inclusions and lobulated muscle fibres (fig. 1c). Dysferlin immunostaining showed a moderately decreased, uneven, sarcolemmal staining in about $30 \%$ of the muscle fibers (fig. 1d). Major histocompatibility complex I immunostaining demonstrated scattered, focal sarcolemmal upregulation of this protein. Electron microscopy showed focal thickening of the basal membrane (fig. 1e), microvilli-like projections of the sarcolemma with numerous subsarcolemmal vesicles, scattered degeneration of the myofibrillar structure, mitochondrial proliferation and amorphous electrodense lipid structures (fig. 1f). Furthermore, interstitial focal accumulation of amyloid filaments was found, as demonstrated by Congo red staining (fig. $1 \mathrm{~g}$ ) and electron microscopy (fig. 1h).

The DYSF gene was analyzed by PCR and sequencing of both DNA strands of

\section{KARGER}

Fax +4161306 1234 E-Mail karger@karger.ch www.karger.com
(C) 2012 S. Karger AG, Basel

0014-3022/12/0675-0300\$38.00/0

Accessible online at:

www.karger.com/ene
István Gáti

Neuromuscular Unit, Department of Neurology

University Hospital

SE-581 85 Linköping (Sweden)

Tel. +4610 103 2049, E-Mail istvan.gati@lio.se 


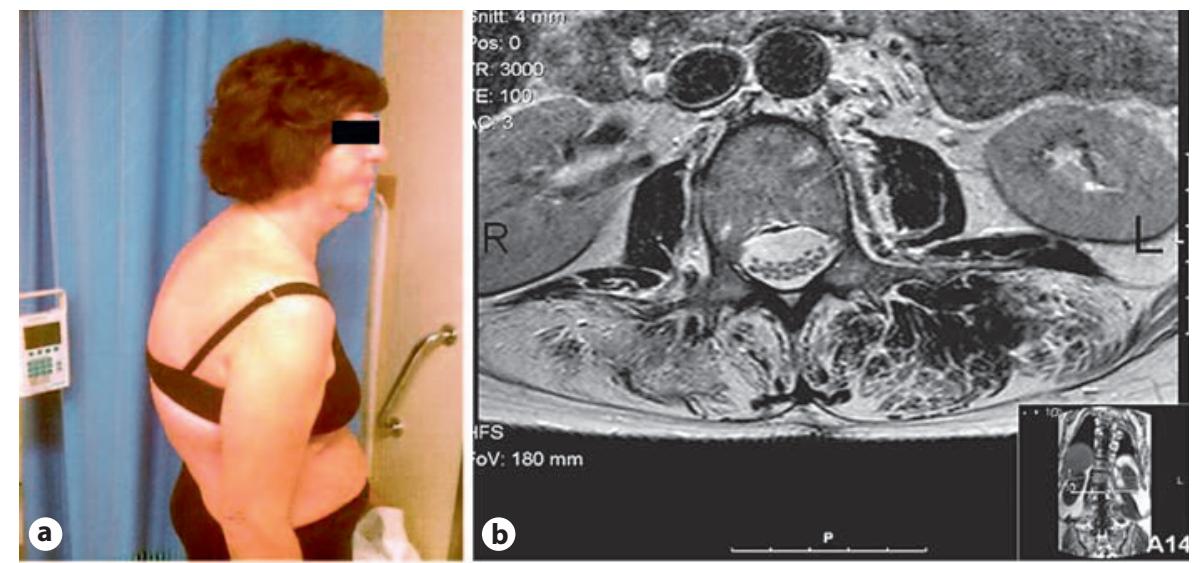

Fig. 1. a Bent spine syndrome. b MRI of paraspinal muscles. c NADH-dehydrogenase staining. d Dysferlin immunostaining. $\mathrm{N}=$ Normal staining; $\mathrm{W}=$ weak, uneven staining. g Congo red staining (arrows show apple-green endomysial amyloid deposits with polarization optic). e, f, h Electron miscroscopy (arrow shows focal thickening of the basal membrane). $\mathrm{a}=$ Amyloid filaments with 5-10 nm diameters; $c=$ collagen filaments with $50-80$ $\mathrm{nm}$ diameters; $\mathrm{d}=$ dense amorphous material; $\mathrm{m}=$ mitochondria.
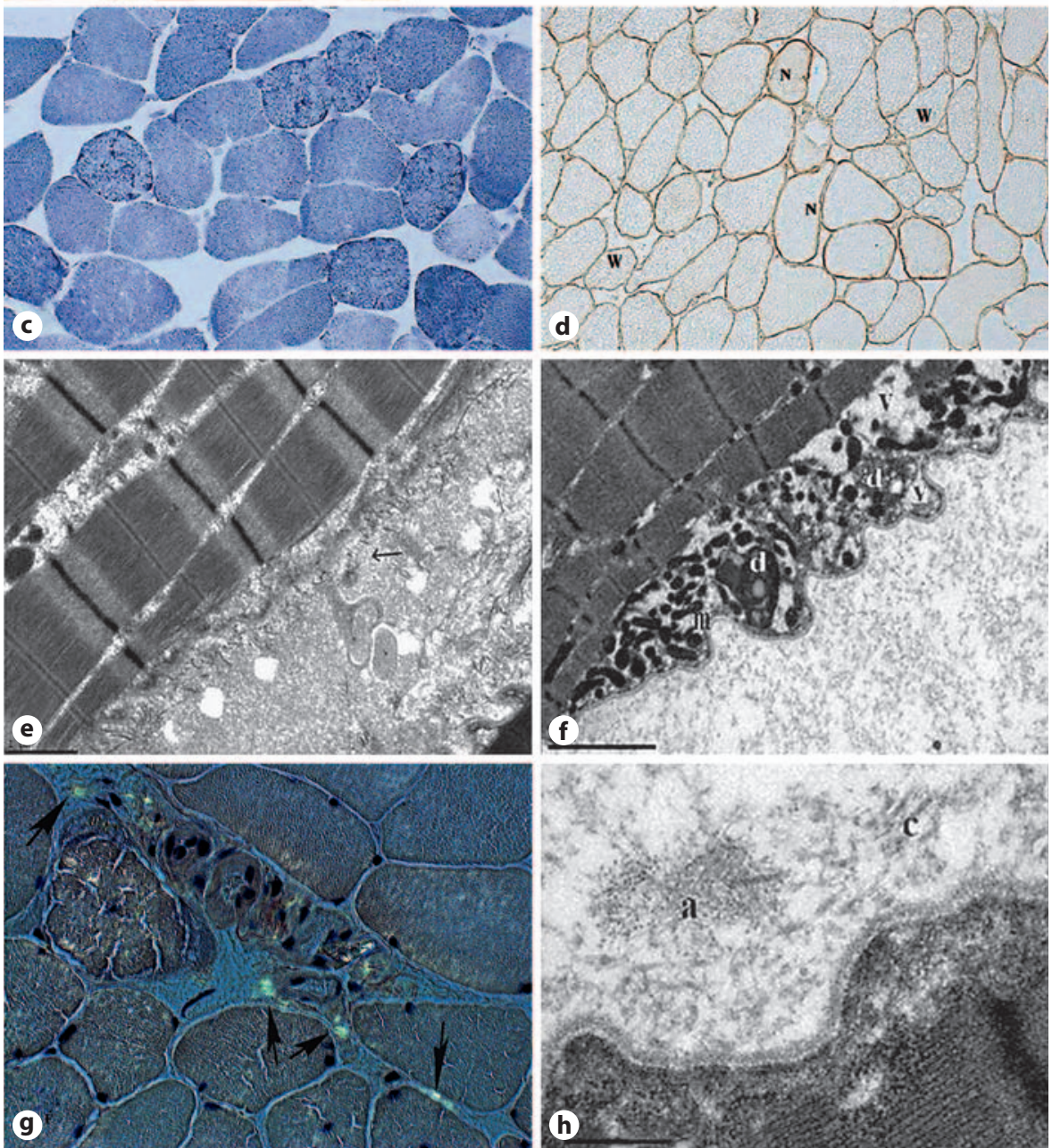

the entire coding region and the highly conserved exon-intron splice junctions. In addition, MLPA analysis was performed to test for deletions or duplications. Molecular genetic investigation found a c. $3065 \mathrm{G}>\mathrm{A}$ heterozygote mutation in exon
29 of the DYSF gene resulting in arginineglutamine exchange (p.R1022Q). PMP22, SMN1 and D4Z4 genes were also investigated, but there were no deletion or multiplication found with multiple ligation probe analysis.

\section{Discussion}

Our patient presented with a progressive course of severe paraspinal muscle weakness and moderate shoulder girdle weakness, with the appearance of bent 
spine syndrome [2]. No any other members of the family presented complaints or signs of muscle disorders, therefore the dominant disease course seemed to be impossible. It has been postulated that an active sport life could contribute to the appearance of the symptoms [11], and impaired sarcolemmal resealing of damaged myofibers could be a key pathomechanism in this disorder [12]. Our patient had normal muscle prowess before the onset of the symptoms. She did not have an active sport life; however, the symptoms first appeared when she was in her fifties.

The laboratory and enzyme investigations did not show abnormalities. EMG of the paraspinal and deltoid muscles demonstrated myopathy, and the MRI investigation showed severe fatty degeneration of the erector spinae muscles. Muscle biopsy showed myopathy with lobulated fibers and slightly abnormal dysferlin staining. Unfortunately, the quantitative dysferlin evaluation by Western blot analysis [13] was not successful. The molecular genetic investigation found a heterozygous DYSF gene mutation, which has been shown to be responsible for muscular symptom [14]. We could not confirm that the patient was suffering from autosomal recessive limbgirdle muscular dystrophy type $2 \mathrm{~B}$ due to mutation in the DYSF gene, because we found no second mutation. It is possible that the patient was a symptomatic DYSF gene mutation carrier; a few cases have been described [15].

We completed our investigations with electron microscopy. Here we found quite similar pathological changes to what has been described and which seem to be characteristic for dysferlinopathy, such as focal myofibrillar disorganisation, mitochondrial proliferation, microvilli-like sarcolemmal projections and proliferation of the basal membrane $[16,17]$. We also found amyloid accumulation, a recently recognized pathological finding in dysferlinopathy which might have a therapeutic impact [18].
Mutations in the gene encoding for dysferlin lead to distinct phenotypes, mainly limb-girdle muscular dystrophy type $2 \mathrm{~B}$ or Myoshi myopathy. To our knowledge, only one previous case history of bent spine syndrome has been published where a DYSF gene mutation could be accounted for this rarely seen symptom. Our patient is the second case where the probable genetic background of a muscle dystrophy presenting as bent spine syndrome is a DYSF gene mutation.

\section{Acknowledgements}

We thank Dr. Arndt Rolfs, Thomas Schwarzbraun, $\mathrm{PhD}$, and Anja Röhle, $\mathrm{PhD}$, CENTOGENE, Institute of Molecular Diagnostics, Rostock, Germany, for the molecular genetic investigations. We thank Gunnvor Sjöö and Liv Gröntoft for excellent technical assistance.

\section{References}

1 Serratrice G, Pouget J, Pellissier JF: Bent spine syndrome. J Neurol Neurosurg Psych 1996;60:51-54.

2 Serratrice G: Clinical semiology of neuromuscular diseases. Bent spine myopathy or syndrome. Acta Myol 2007;26:1-4.

- 3 Seror P, Krahn M, Laforet P, Leturcq F, Maisonobe $\mathrm{T}$ : Complete fatty degeneration of lumbar erector spinae muscles caused by a primary dysferlinopathy. Muscle Nerve 2008;37:410-414.

-4 Kottlors M, Kress W, Meng G, Glocker FX: Facioscapulohumeral muscular dystrophy presenting with isolated axial myopathy and bent spine syndrome. Muscle Nerve 2010;42: 273-275.

5 Kastrup A, Gdynia HJ, Nägele T, Riecker A: Dropped-head syndrome due to steroid responsive focal myositis: a case report and review of the literature. J Neurol Sci 2008;267: 162-165.

6 Kuo SH, Vullaganti M, Jimenez-Shahed J, Kwan JY: Camptocormia as a presentation of generalized inflammatory myopathy. Muscle Nerve 2009;40:1059-1063.
7 Wakata N, Konno S, Nomoto N, Sugimoto H, Nemoto H, Kurihara T, Kishi M: Myasthenia gravis with concomitant severe paraspinal muscle degeneration and mitochondrial DNA4977 deletion. Intern Med 2007;46:747750.

8 Friedman Y, Paul JT, Turley J, Hazrati LN, Munoz D: Axial myopathy due to primary amyloidosis. Muscle Nerve 2007;36:542546.

-9 Jungbluth H, Lillis S, Zhou H, Abbs S, Sewry C, Swash M, Muntoni F: Late-onset axial myopathy with cores due to a novel heterozygous dominant mutation in the skeletal muscle ryanodine receptor (RYR1) gene. Neuromuscul Disord 2009;19:344-347.

10 Jordan B, Eger K, Koesling S, Zierz S: Camptocormia phenotype of FSHD: a clinical and MRI study on six patients. J Neurol 2011;258: 866-873.

$\checkmark 1111$ Klinge L, Aboumousa A, Eagle M, Hudson J, Sarkozy A, Vita G, et al: New aspects on patients affected by dysferlin deficient muscular dystrophy. J Neurol Neurosurg Psychiatry 2010;81:946-953.

-12 Bansal D, Miyake K, Vogel SS, Groh S, Chen CC, Williamson R, et al: Defective membrane repair in dysferlin-deficient muscular dystrophy. Nature 2003;423:168-172.
13 Fanin M, Nascimbeni AC, Angelini C: Muscle protein analysis in the detection of heterozygotes for recessive limb girdle muscular dystrophy type 2B and 2E. Neuromuscul Disord 2006;16:792-799.

14 Cagliani R, Fortunato F, Giorda R, Rodolico C, Bonaglia MC, Sironi M, et al: Molecular analysis of LGMD-2B and MM patients: identification of novel DYSF mutations and possible founder effect in the Italian population. Neuromuscul Disord 2003;13:788-795.

15 Illa I, De Luna N, Domínguez-Perles R, Rojas-García R, Paradas C, Palmer J, et al: Symptomatic dysferlin gene mutation carriers: characterization of two cases. Neurology 2007;68:1284-1289.

16 Selcen D, Stilling G, Engel AG: The earliest pathologic alterations in dysferlinopathy. Neurology 2001;56:1472-1481.

- 17 Cenacchi G, Fanin M, De Giorgi LB, Angelini C: Ultrastructural changes in dysferlinopathy support defective membrane repair mechanism. J Clin Pathol 2005;58: 190-195.

- 18 Spuler S, Carl M, Zabojszcza J, Straub V, Bushby K, Moore SA, et al: Dysferlin-deficient muscular dystrophy features amyloidosis. Ann Neurol 2008;63:323-328. 